\title{
PERSPEKTIF GENDER DALAM HISTORIOGRAFI INDONESIA
}

\author{
Desma Yulia \\ Dosen Tetap Prodi Pendidikan Sejarah Universitas Riau Kepulauan Batam
}

\section{PENDAHULUAN}

Selama ini, penulisan sejarah khususnya sejarah Indonesia di bangun dalam kacamata laki-laki semata-mata. Meskipun kadang-kadang perempuan ditampilkan dalam sejarah, namun tidak lebih sebagai pelengkap, atau ranah yang dikonstruksikan dalam budaya patriakhis yang selalu memihak dan untuk kepentingan laki-laki. Ambil saja sebagai contoh periodesasi sejarah revolusi dalam sejarah Indonesia, perempuan paling sering diungkapkan keterlibatan perannya di dalam dapur umum. Sangat sulit menemukan tulisan-tulisan dari sekian banyak karya-karya tentang sejarah revolusi yang mengungkapkan perempuan dalam bentuk lainnya. Artinya kacamata yang digunakan adalah bahwa urusan dapur, yang dalam perspektif jender lebih dikenal dengan ranah domestic merupakan tempat bagi perempuan semata-mata. Meskipun terdapat pengungkapan tentang lascar-laskar perempuan itu hanya tetap dalam posisi mengisi bunga-bunga sejarah, dengan kata lain sebagai peran tambahan (supplement). Perspektif patriakhis menilai bahwa peran tersebut bukanlah pekerjaan kaum perempuan. Sebuah ulasan kritis pernah dilontarkan oleh sejarawan Christine Dobbin (1979) dari Australian National University tentang kenapa absennya perempuan dalam sejarah revolusi Indonesia ${ }^{1}$.

\section{KAJIAN TEORI}

Dalam Women's Studies Encyclopedia menjelaskan bahwa gender adalah suatu konsep cultural yang berupaya membuat perbedaan dalam hal peran, prilaku, mentalitas, dan karakteristik emosional antara laki-laki dan perempuan yang berkembang dalam masyarakat. Hillary M.Lips dalam bukunya yang terkenal Sex And Gender: An Introduction mengartikan gender sebagai harapan-harapan budaya terhadap laki-laki dan perempuan (cultural expectation for woman and men).

Membahas permasalahan gender berarti membahas permasalahan perempuan dan juga laki-laki dalam kehidupan masyarakat. Dalam pembahasan mengenai gender, termasuk kesetaraan dan keadilan gender dikenal adanya 2 aliran atau teori yaitu teori nurture dan teori nature. Namun demikian dapat pula dikembangkan satu konsep teori yang di ilhami dari dua konsep teori tersebut yang merupakan kompromistis atau keseimbangan yang disebut dengan teori egquilibrium.

\footnotetext{
${ }^{1}$ Christine Dobbin. 1979. The Seach of Women in Indonesian History", dalam Ailsa Thomson Zain'ddin )et.al), Kartini Centenary: Indonesian Women Then and New, Clayton, Vic. Monash University, Centre of Southeast Asian Studies
} 


\section{a. teori Nurture}

Menurut teori nurture adanya perbedaan perempuan dan laki-laki adalah hasil konstruksi social budaya sehingga menghasilkan peran dan tugas yang berbeda. Perbedaan itu membuat perempuan selalu tertinggal dan terabaikan peran dan kontribusinya dalam kehidupan dan laki-laki dalam perbedaaan kelas. Laki-laki diidentikkan dengan kelas borjous, dan perempuan sebagai kelas proletar.

\section{b. Teori Nature}

menurut teori nature adanya perbedaan laki-laki dan perempuan adalah kodrat, sehingga harus diterima. Perbedaan biologis itu memberikan indikasi dan implikasi bahwa diantara kedua jenis kelamin tersebut memiliki peran dan tugas yang berbeda. Ada peran dan tugas yang dapat dipertukarkan, tetapi ada yang tidak bisa karena memang berbeda secara kodrat alamiahnya.

\section{PEMBAHASAN}

Kajian tentang sejarah Indonesia dengan pendekatan ilmu-ilmu social khususnya gender masih dapat dikategorikan langka di Indonesia ${ }^{2}$. Umumnya studi-studi tentang perempuan masih terbatas dan didominasi dengan tema-tema pemberdayaan perempuan atau gender mainstreaming bukan woman history yang lebih mengutamakan perspektif feminisnya ketimbang gender. Sementara studi-studi tentang sejarah Indonesia masih banyak mengalami "bias gender". Artinya hamper keseluruhan peristiwa yang diungkapkan dalam sejarah Indonesia sangat didominasi oleh pria sebagai actor utamanya.

Ada kemungkinan beberapa factor yang membuat penulisan sejarah perempuan ini terabaikan dan tergolong lambat perkembangannya disbanding sejarah social lainnya. Pertama, paradigm yang keliru tentang sejarah perempuan. Banyak pendapat beranggapan bahwa segala sesuatu yang berhubungan dengan masalah perempuan adalah persoalan-persoalan domestic. Sementara urusan keilmuan dianggap berhubungan dengan dunia public yang identik dengan dunia pria. Dominannya perspektif patriakhis ini menyebabkan perkembangan sejarah perempouan tertatih-tatih di Indonesia. Kedua, metodologi, perspektif yang keliru tentang dunia perempuan sangat berpengaruh kepada factor lainnya. Diantaranya adalah persoalan metodologi dan sumber, karena perempuan dianggap berurusan dengan persoalan-persoalan prifat, sementara sebagian besar dokumen berurusan dengan persoalanpersoalan public, yang didominasi oleh dunia pria, maka tidak tertutup kemungkinan, perempuan luput dan terabaikan dari catatatn sejarah ${ }^{3}$. Sulitnya menemukan sumber-sumber tentang masa lampau yang

\footnotetext{
${ }^{2}$ Siti Fatimah, 2006. "Negara dan Perempuan:Fujinkai (1983-1945) dan Dharma Wanita (1974-1999)" ringkasan disertasi, dalam Jurnal Masyarakat Indonesia. Jakarta: LIPI, Jilid XXXII

${ }^{3}$ Bambang Purwanto, 2006.Gagalnya Historiografi Indonesiasentris. Yogyakarta: Ombak
} 
berhubungan dengan perempuan sebagai actor sejarah merupakan salah satu penyebab sulitnya penggarapan sejarah perempuan. Di sisi lain, penulisan sejarah di Indonesia masih banyak terperangkap pada peristiwa-peristiwa politik dalam skala besar.

Namun, jika dibandingkan dengan disiplin antropologi, sosiologi, psikologi dan ilmu-iudi sejarah berurusan dengan ilmu social lainnya, maka perkembangan ilmu-ilmu ini terhadap studi perempuan jauh lebih maju daripada sejarah perempuan. Ini dapat dibuktikan dengan sudah banyaknya tulisan-tulisan dan karya-karya yang hadir tentang perempuan dari berbagai bidang disiplin ilmu tersebut, termasuk lingistik. Hal ini dapat dipahami bahwa st udi sejarah berurusan dengan masa lampau. Pokok persoalan studi sejarah berbeda dengan pokok persoalan ilmu-ilmu lainnya. Salah satu contoh adalah tipe eksplanasi yang dimiliki ilmu sejarah itu sendiri. Eksplanasi sejarah berkaitan erat dengan hokum kausalitas dalam ilmu sejarah itu sendiri. Hukum kausalitas tidak hanya merupakan karakteristik dari ilmu sejarah itu sendiri, tetapi juga merupakan suatu karakteristik bagaimana sesungguhnya membangun fakta sejarah (masa lampau) ${ }^{4}$

Eksplanasi kausalitas dalam ilmu sejarah memperlihatkan dua karakteristik penting. Pertama, kapan fakta dijelaskan dalam tempat tersendiri, dan kedua sejarawan harus mampu menempatkan dua fakta saling berhubungan. Sejalan dalam uraian Walsh dalam bukunya Philosophy of history, juga banyak berbicara tentang metodologi sejarah. Walsh juga menekankan masalah ekplanasi sejarah, kebenaran dan fakta dalam sejarah serta masalah objektifitas. Dalam menjelaskan eksplanasi sejarah, Wals lebih banyak dipengaruhi oleh Collingwood dengan dua proposisi utama. Pertama, sejarah adalah berhubungan dengan pemikiran dan pengalaman manusia, dan kedua sejarah adalah berhubungan dengan hal-hal yang unik ${ }^{5}$. Dengan demikian, berhubung studi sejarah harus menjelaskan masa lampau dari fakta yang dibangun, maka studi sejarah tentu memiliki kekhasan dan perbedaan tersendiri dari ilmu-ilmu social lainnya. Anggapan miskinnya sumber-sumber tentang perempuan yang akan menjelaskan fakta sejarah, merupakan salah satu kendala lambatnya berkembang studi sejarah perempuan di Indonesia. Anggapan demikian sebetulnya bisa diatasi dengan berbagai pendekatan dan metode.

Di Amerika dan Eropa banyak cara yang sudah dilakukan sejarawan untuk mengkaji sejarah perempuan. Dalam persoalan metode misalnya kelangkaan sumber tertulis dibantu dengan memperdalam atau mempertajam sumber lisan (oral history). Dalam hal pendekatan dan metodologi dapat dilihat dari pentingnya peran gender. Lyn Hunt dalam bukunya The New Cultural History, melihat bagaimana pentingnya peran gender sebagai sejarah social dan kebudayaan ${ }^{6}$. Di Amerika Serikat sejarah perempuan menempati garis terdepan dalam perkembangan sejarah kebudayaan baru. Implikasi

\footnotetext{
${ }^{4}$ Patick Gardiner, 1962. The Nature of Historical Explanation. London: Oxford University

${ }^{5}$ W.H.Wals, 1961. Philosophy of History:An Introduction. Harper Totchbook

${ }^{6}$ Lyn Hunt, 1989. The New Cultural History.Berkeley University: California Press
} 
studi gender diperlihatkan oleh Joan Scott dalam kumpulan essaynya yang berjudul Gender and Politics of History. Scott melihat secara lebih khusus dalam hubungan sejarah gender dan analisis wacana dengan memadukan teori gener dan sastra

Sejak tahun 1997 lebih dari 1.700 buku sejarah Indonesia yang diterbitkan. Dari sekian banyak itu, hanya 2 persen yang membahas dan menyinggung tentang perempuan ${ }^{7}$. Begitupun, hampir diseluruh Kabupaten/Kota di Indonesia telah menulis buku sejarah perjuangannya pada masa revolusi atau masa perjuangan kemerdekaan. Hampir seluruh buku-buku yang ditulispun tidak cukup 1 persen menempatkan perempuan dalam proses sejarah revolusi tersebut. Dari data tersebut dengan jelas menunjukkan bahwa telah terjadi ketimpangan yang signifikan dalam penulisan sejarah Indonesia sampai saat ini. Hal ini menunjukkan bahwa historiografi Indonesia sangat bersifat Androcentris, yaitu penulisan sejarah yang masih berpusat kepada kepentingan laki-laki.

Hal yang sama juga dilakukan oleh sejarawan asing yang Indonesianist. Bahkan seorang sejarawan asing yang cukup ternama menulis sejarah revolusi Indonesia dengan judul "Revolusi Pemuda”. Tidaklah mengherankan jika karya-karya sejarah revolusi diakui oleh Robert Gribb (1997) dan Anton Lucas (1997) memiliki ketimpangan dan bias jender. Sebagaimana yang mereka ungkapkan dalam makalahnya pada konferensi internasional "Revolusi Nasional:Kajian, Kenangan, dan Renungan", saat memperingati 50 tahun Indonesia merdeka.

“ Kami telah mempersiapkan buku guna memperbaiki ketimpangan itu, dan juga kami menganggap bahwa dengan memusatkan perhatian pada pengalaman perempuan, perhatian kita terhadap sejarah revolusi yang penting bagi orang Indonesia tidak luput begitu saja"

Kutipan yang disampaikan oleh sejarawan ahli revolusi ini, menunjukkan bahwa telah terjadi ketidakadilan yang berbasis jender dalam penulisan sejarah revolusi selama ini. Oleh karena itu, mereka merasa bertanggungjawab untuk mengoreksi kembali tentang penelitian dan penulisan di masa revolusi tersebut.

Jika dilakukan penelitian tentang tulisan-tulisan atau karya-karya sejarah Indonesia, baik dalam bentuk buku, skripsi, tesis, sampai disertasi dan termasuk proyek-proyek penelitian sejarah baik yang dilakukan secara individu maupun kelompok akan terbukti bahwa historiografi sejarah Indonesia adalah historiografi Androsentris. Namun sebagaimana yang telah disinggung pada bagian terdahulu, dengan perkembangan metodologi baru, penulisan sejarah yang bersifat androsentris mulai dipertanyakan dan ditinggalkan. Meskipun hal yang demikian akan memakan waktu dan proses yang cukup lama.

\footnotetext{
${ }^{7}$ Maria Hartiningsih, "Perspektif Historiografi Feminis dalam Penulisan Sejarah", makalah disampaikan pada lokakarya Historiografi Indonesia di Yogyakarta, yang diselenggarakan oleh pusat Studi Asia Tenggara, Universitas Gajahmada, Senin 30 Juli 2007.http:/www.Kompas.com/kompas cetak/0707/30/swara/3723121.htm
} 


\section{Tema-tema dalam penulisan sejarah perempuan}

Jika sebuah paradigma baru (new history) tela terbangun tidak sulit untuk menulis sejarah yang berkeadilan jender. Pendekatan ilmu-ilmu sosial atau multi dimensional, yang pernah sangat spektakuler dalam historiografi dan metodologi penulisan sejarah Indonesia masih sangat penting dipergunakan sebagai pendekatan yang bersifat umum. Di sisi lain, pendekatan spesifik dapat ditarik dari teori-teori feminis dan jender. Karena sejarawan menempatkan teori lebih bermanfaat untuk membuat pertanyaan daripada menemukan jawaban ${ }^{8}$. Pada sisi lain, feminisme telah menyumbang tidak secara langsung bagi penulisan sejarah generasi lampau. Sama seperti sejarah dari kalangan bawah, sejarah perempuan memberikan perspektif baru tentang masa lampau, yang sampai sekarang konsekuensinya masih belum terfikirkan.

Berangkat dari beberapa pendekatan baru yang ditawarkan, banyak sekali tema-tema yang bisa diangkat dalam penulisan sejarah perempuan. Dalam hal ini dicoba untuk mengkatagorikannya kedalam tiga tema besar. Pertama, perempuan dalam berbagai struktur kelembagaan dan organisasi. Kedua, perempuan dalam berbagai event-event tertentu di dalam proses historis. Ketiga, life history perempuan. Pada kategori pertama dapat ditekankan pada peran dan status perempuan dalam organisasi-organisasi atau lembaga-lembaga tertentu. Misalnya, organisasi-organisasi perempuan pada masa pergerakan; Poteri Mardika, Aisyiah, Persatuan Isteri Sedar dan seterusnya. Organisasi-organisasi perempuan pada masa perang kemerdekaan, pada masa Orde Lama, seperti Gerwani, yang akhir-akhir ini sangat banyak diminati dan di dekonstruksi lagi. Tulisan yang menarik dan fundamental tentang organisasi ditulis oleh Saskia Wierna dengan judul 'Kuntil Anak Wangi: Organisasi Perempuan Setelah tahun 50-an'. Kemudian, organisasi perempuan pada masa Orde Baru, seperti Dharma Wanita, PKK dan seterusnya. Di samping itu, bermacam pendekatan dan aspek teori bisa dipakai untuk mengkaji seluruh organisasiorganisasi ini dengan kritis.

Kemudian tema-tema yang berhubungan dengan event-event tertentu dalam proses histrois. Misalnya, Kongres Perempuan I pada masa pergerakan, Confort Women pada masa Perang Dunia I, Iugun Janfu pada masa pendudukan Jepang, mata-mata dan kurir perempuan pada masa revolusi, buruh perempuan pada masa Tanam Paksa, bentuk-bentuk gerakan perempuan dalam masing-masing periode tertentu, dan seterusnya. Terakhir dalam bentuk life history, mengkaji pengalaman perempuan dalam berbagai bentuk, bisa saja dalam bentuk biografi dan pospografi perempuan tersebut atau pengalamanpengalaman lain yang dilakukan perempuan, misalnya pedagang perempuan, tukang jamu, dan lainlain.

Sejalan dengan tema-tema yang dikategorikan di atas Gerda Lerner melihat tiga tahapan dalam penulisan sejarah perempuan. Pertama, compensatory history,yang mempertanyakan apa dan

${ }^{8}$ Peter Burke, (terj), 2001. Sejarah dan Teori Sosial. Jakarta: Obor 
bagaimana peran perempuan. Kedua, contribution history, yaitu apa yang disumbangkan perempuan dalam event-event tertentu. Ketiga adalah movement history, bangkitnya kesadaran perempuan dalam berbagai macam bentuk gerakan. Contoh-contoh yang dikemukakan ini, baru merupakan sebagian kecil dari topic-topik sejarah yang bisa diteliti dan ditulis. Apa yang dikemukakan di atas juga bukan merupakan harga mati, sebab banyak sekali yang mungkin bisa kita diskusikan.

\section{PENUTUP}

Dari ratusan karya sejarah Indonesia, ternyata historiografi Indonesia telah mengalami banyak distorsi. Studi historiografi sebagai bagian dari langkah metode sejarah dan sebagai bidang disiplin tersendiri dalam keilmuan sejarah memberikan kontribusi penting untuk mengkritisi karya-karya sejarah yang telah ditulis oleh sejarawan. Ketika kongres Sejarah Nasional I di Yogyakarta pada tahun 1957 sepakat untuk mengkritisi penulisan sejarah Indonesia yang bersifat Indonesiasentris yang menggantikan sejarah kolonialsentris. Namun ironisnya, sesuai dengaan perkembangan zaman dan ilmu pengetahuan historiografi Indonesia selalu mendapatkan tantangan terus, lebih-lebih setelah tahun 1970-an ketika ilmu ini semakin matang dan selalu berdialog dengan ilmu-ilmu lainnya. Salah satu diantaranya adalah bahwa telah terjadi kesalahan yang serius dalam penulisan sejarah Indonesia selama ini, terutama dalam ketidakadilan sejarah yang berprespektif laki-laki dan perempuan. Dunia sejarah mulai dibangunkan bahwa yang memiliki sejarah di masa lampau ternyata bukan yang berjenis kelamin laki-laki semata-mata.

\section{DAFTAR PUSTAKA}

Bambang Purwanto, 2006.Gagalnya Historiografi Indonesiasentris. Yogyakarta: Ombak

Christine Dobbin. 1979. The Seach of Women in Indonesian History", dalam Ailsa Thomson Zain'ddin )et.al), Kartini Centenary: Indonesian Women Then and New, Clayton, Vic. Monash University, Centre of Southeast Asian Studies

Lyn Hunt, 1989. The New Cultural History.Berkeley University: California Press

Maria Hartiningsih, "Perspektif Historiografi Feminis dalam Penulisan Sejarah", makalah disampaikan pada lokakarya Historiografi Indonesia di Yogyakarta, yang diselenggarakan oleh pusat Studi Asia Tenggara, Universitas Gajahmada, Senin 30 Juli 2007.http:/www.Kompas.com/kompas cetak/0707/30/swara/3723121.htm

Patick Gardiner, 1962. The Nature of Historical Explanation. London: Oxford University

Peter Burke, (terj), 2001. Sejarah dan Teori Sosial. Jakarta: Obor 